\title{
Performance and Electrochemical Characterisation of Thin Electrolyte SOFCs
}

Ramos, Tania; Hjelm, Johan; Wandel, Marie; Hagen, Anke; Mogensen, Mogens Bjerg

Published in:

Meeting Abstracts - Electrochemical Society

Publication date:

2008

Document Version

Publisher's PDF, also known as Version of record

Link back to DTU Orbit

Citation (APA):

Ramos, T., Hjelm, J., Wandel, M., Hagen, A., \& Mogensen, M. B. (2008). Performance and Electrochemical Characterisation of Thin Electrolyte SOFCs. In Meeting Abstracts - Electrochemical Society (pp. Abstract 377). The Electrochemical Society.

\section{General rights}

Copyright and moral rights for the publications made accessible in the public portal are retained by the authors and/or other copyright owners and it is a condition of accessing publications that users recognise and abide by the legal requirements associated with these rights.

- Users may download and print one copy of any publication from the public portal for the purpose of private study or research.

- You may not further distribute the material or use it for any profit-making activity or commercial gain

- You may freely distribute the URL identifying the publication in the public portal

If you believe that this document breaches copyright please contact us providing details, and we will remove access to the work immediately and investigate your claim. 


\section{Performance and electrochemical characterisation of} thin electrolyte SOFCs

T. Ramos, J. Hjelm, M. Wandel, A. Hagen, M. Mogensen Fuel Cells and Solid State Chemistry Department Risø National Laboratory - DTU

P.O. Box 49, DK - 4000 Roskilde, Denmark

Anode supported thin electrolyte SOFCs, consisting of tape-casted anode support, sprayed YSZ electrolyte, sprayed Ni/YSZ cermet anode and LSM composite cathode, are produced on a pre-pilot plant scale at Risoe National Laboratory. Their performance and properties were reported earlier [1,2]. Cells of the same type, but with screen-printed cathode and half-cell layers manufactured by tape-casting, are currently being developed and tested for performance and durability. They are also being examined in terms of microstructure.

To assist optimisation and gain further insight on the behaviour of each cell component, it is necessary to break down and assign the losses into the various components. However, thin electrolyte cells cannot be used to measure anode and cathode losses separately using a reference electrode [3]. Although individual electrode performances can be investigated on symmetrical cells, manufacturing processes usually differ from those used for full cells, hindering a direct comparison.

The cell resistance is the sum of several contributions, comprising ohmic, concentration polarisation and electrode polarisations. Identifying and assigning these to individual processes and/or cell component is a complex task. It has been previously demonstrated with a pre-pilot anode supported thin electrolyte cell [2], that individual contributions to the total cell resistance could be obtained by deconvolution of the impedance spectra. The deconvolution was helped by information gathered mostly from symmetrical cell testing, particularly regarding the individual characteristics of the two electrodes. The aim of the present work is to apply a similar methodology and perform a systematic electrochemical characterisation on the newly developed cells, with particular focus on anode characterisation.

Full cell investigations are carried out on flat anode supported $5 \times 5 \mathrm{~cm}^{2}$ cells with an active area of $4 \mathrm{x}$ $4 \mathrm{~cm}^{2}$, with varying anode and electrolyte compositions and different production parameters. The cells are tested at temperatures between $650-850{ }^{\circ} \mathrm{C}$, with air as cathode gas and $20 \% \mathrm{H}_{2} \mathrm{O}-80 \% \mathrm{H}_{2}$ and $4 \% \mathrm{H}_{2} \mathrm{O}-96 \% \mathrm{H}_{2}$ as fuel gas. Impedance spectra and $\mathrm{i}-\mathrm{V}$ characteristics are obtained for each different test condition. Impedance spectra of symmetrical cells with anode support and symmetrical cells with cathode are obtained in oneatmosphere setups at relevant temperatures. The full cell and symmetrical cell spectra are fitted to suitable equivalent circuits and the full cell impedance data compared to the DC data obtained. The results are linked/correlated to production parameters, and where possible explained in terms of composition and microstructure.

Figure 1 shows the impedance spectra and Figure 2 the $\mathrm{i}-\mathrm{V}$ characteristics of a cell manufactured using the new procedure. The ASR $/ R_{\mathrm{p}} / \mathrm{R}_{\mathrm{s}}$ values obtained for this cell were, respectively, $0.33 / 0.32 / 0.15 \Omega \mathrm{cm}^{2}$ at $750^{\circ} \mathrm{C}$ and $0.17 / 0.16 / 0.08 \Omega \mathrm{cm}^{2}$ at $850^{\circ} \mathrm{C}\left(20 \% \mathrm{H}_{2} \mathrm{O}-80 \% \mathrm{H}_{2}\right)$, where ASR is the total area specific resistance, $R_{p}$ is the area specific polarisation resistance of the electrodes (at OCV) and $\mathrm{R}_{\mathrm{s}}$ is the area specific series resistance, mainly arising from the electrolyte. The ASR values were corrected for fuel utilisation [3].

The performance of the newly developed cells is already comparable to those obtained on standard prepilot cells with screen-printed cathodes, indicating that the simpler tape casting methods have a clear potential for further improvements of the cell performance. The proposed in-depth electrochemical characterisation will enable further understanding of cell behaviour, and can provide valuable guidelines for production/performance optimisation.

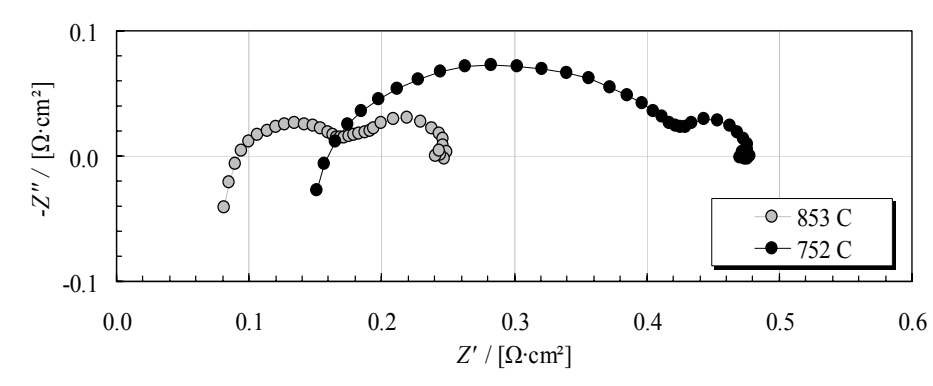

Figure 1: Impedance spectra of an anode supported thin electrolyte cell (Tape-casted: anode support, Ni/YSZ anode, YSZ electrolyte; Screen-printed: LSM/YSZ cathode) in $20 \% \mathrm{H}_{2} \mathrm{O}-80 \% \mathrm{H}_{2}$ at $750{ }^{\circ} \mathrm{C}$ and $850{ }^{\circ} \mathrm{C}$.

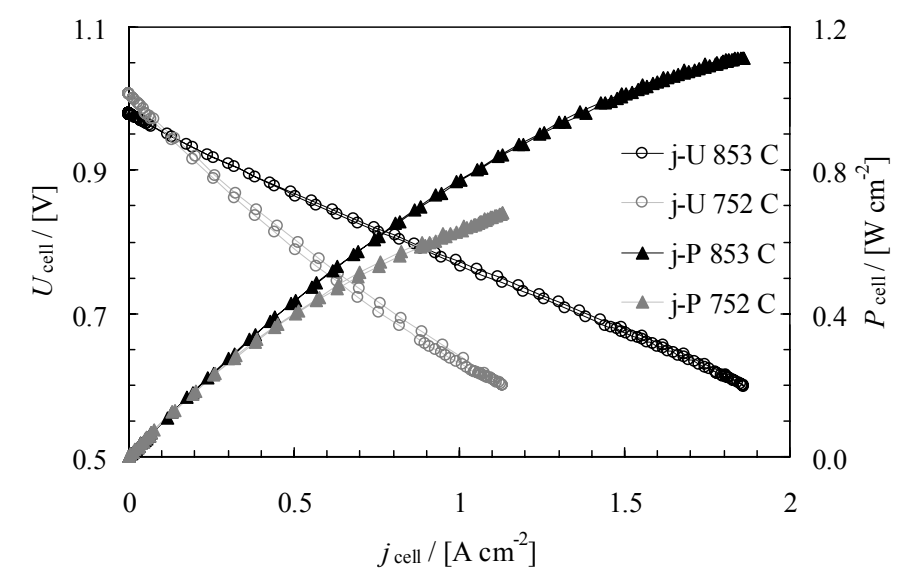

Figure 2: $i-V$ amd i-P characteristics of an anode supported thin electrolyte cell (Tape-casted: anode support, Ni/YSZ anode, YSZ electrolyte; Screen-printed: LSM/YSZ cathode) in $20 \% \mathrm{H}_{2} \mathrm{O}-80 \% \mathrm{H}_{2}$ at $750{ }^{\circ} \mathrm{C}$ and $850^{\circ} \mathrm{C}$.

\section{Acknowledgements}

The authors wish to thank Mrs. K. Brodersen, Dr. N. Bonanos, Dr R. Knibbe and all those involved in the cell tests. Financial support from Energinet.dk through PSO project no. 7124 SOFC R\&D is gratefully acknowledged.

[1] A. Hagen, M. Menon, R. Barford, P.V. Hendriksen, S. Ramousse, P.H. Larsen, Fuel Cells 06, 2006, No. 2, 146150

[2] R. Barford, A. Hagen, S. Ramousse, P.V. Hendriksen, M. Mogensen, Fuel Cells 06, 2006, No. 2, 141-145

[3] M. Mogensen and P. V. Hendriksen in High Temperature Solid Oxide Fuel Cells, S. C. Singhal and K. Kendall, Editors, Chapter 10, p. 261, Elsevier Ltd., (2003) 